\title{
Autoradiographic analysis of changes in ovarian binding of FSH and hCG during induced follicular atresia in the hamster
}

\author{
Chandrima Shaha and G. S. Greenwald \\ Department of Physiology, Ralph L. Smith Research Center, University of Kansas Medical \\ Center, Kansas City, Kansas 66103, U.S.A.
}

\begin{abstract}
Summary. Immediately after hypophysectomy, 30 i.u. PMSG were injected s.c. and 3 days later an antiserum to PMSG was injected i.p. Groups of hamsters were killed at $0,24,48$ and $72 \mathrm{~h}$ after PMSG antiserum. The ovaries were prepared for topical autoradiography and the numbers of silver grains in different ovarian compartments were counted. The numbers of binding sites for ${ }^{125}$ I-labelled FSH in the granulosa cells of the antral follicles dropped sharply to 33,14 and $5 \%$ of that at $0 \mathrm{~h}$ at 24,48 and $72 \mathrm{~h}$ respectively. Binding of ${ }^{125} \mathrm{I}$-labelled hCG to granulosa cells declined more slowly, being 47,27 and $24 \%$, respectively. Binding of ${ }^{125}$ I-labelled hCG to thecal and interstitial cells was unaffected. Compared to other models of atresia, the changes in gonadotrophin binding observed in this model occur at an accelerated rate because of the acute deprivation of PMSG.
\end{abstract}

\section{Introduction}

The majority of ovarian follicles are destined to become atretic at some phase of their life cycle but because of the random nature of follicular death it is difficult to analyse the associated steroidogenic, biochemical and morphological changes. Accordingly, several animal models have been proposed which provide a more definite time scale for the inception of atresia: blockade of ovulation in pro-oestrous animals by administration of barbiturates (rat: Braw \& Tsafriri, 1980a; hamster: Terranova, 1980); hypophysectomy of cyclic animals with large antral follicles in the ovaries (Talbert, Meyer \& McShan, 1951); injection of immature animals with PMSG and evaluation of the subsequent temporal changes in the ovaries (mouse: Byskov, 1979; rat: Braw \& Tsafriri, 1980b).

A model developed in this laboratory (Greenwald, 1963, 1973) which gives a very precise start for the onset of follicular atresia involves the administration of PMSG to hypophysectomized hamsters followed $72 \mathrm{~h}$ later by an i.p. injection of an antiserum to PMSG. This results in acute deprivation of gonadotrophins to the extent that within $1 \mathrm{~h}$ serum oestradiol levels have fallen from $1030 \mathrm{pg} / \mathrm{ml}$ to $461 \mathrm{pg} / \mathrm{ml}$ (Bill \& Greenwald, 1981).

Atresia has been postulated to be caused by a decrease in sensitivity to gonadotrophins (Richards \& Midgley, 1976) and a decrease in gonadotrophin receptors occurs in rat follicles with advancing atresia (Uilenbroek, Woutersen \& van der Schoot, 1980). In the hamster, cyclic nucleotides decrease with time in atretic antral follicles and this may be related to changes in the numbers or properties of gonadotrophin receptors (Hubbard \& Greenwald, 1981).

The purpose of the present study was to quantify the changes occurring in binding sites for gonadotrophins in this hamster model of atresia by topical autoradiography (Bortolussi, Marini 
\& Reolon, 1979) which involves the application of radioiodinated FSH and hCG to fixed frozen sections of ovary. The latter hormone was used instead of $\mathrm{LH}$ because both hormones share the same receptors but hCG is less damaged by iodination and is more stable.

\section{Materials and Methods}

Female hamsters (Mesocricetus auratus) weighing 80-120 g were maintained in lighting of $14 \mathrm{~h}$ light : $10 \mathrm{~h}$ dark (lights on at 05:00 h). The day of ovulation (Day 1) was detected by the copious vaginal discharge. The animals underwent a minimum of 3 cycles before treatment. They were hypophysectomized via a parapharyngeal approach on the morning (09:00-10:00 h) of Day 1 of the cycle. Immediately after surgery, 30 i.u. PMSG were injected s.c. On Day 4, $100 \mu$ antiserum to PMSG was injected i.p. at 09:00 h. The antiserum to PMSG was raised in rabbits by Dr D. C. Johnson and has been previously characterized for the hamster by Bill \& Greenwald (1981). A control group (Group 0) consisted of hypophysectomized PMSG-treated hamsters which received no antiserum and were killed on the morning of Day 4 at 09:00 $\mathrm{h}$. The other animals were killed 24,48 or $72 \mathrm{~h}$ after the antiserum injection (Groups 1, 2 and 3, respectively). In a second set of experiments to test the effectiveness of PMSG in sustaining follicular development beyond Day 4, animals were treated as in Groups 0 and 1 and a third group was treated with $100 \mu \mathrm{l}$ normal rabbit serum at 09:00 h on Day 4 and killed $24 \mathrm{~h}$ later.

Tissue processing. The ovaries were placed in cryoembedding medium and frozen over liquid nitrogen. Sections were cut at $10 \mu \mathrm{m}$ in a freezing microtome kept at $-20^{\circ} \mathrm{C}$. The sections were fixed in picric acid-paraformaldehyde fixative and washed in $0.01 \mathrm{M}$-phosphate buffered saline (PBS, pH 7.0), air dried and stored in $-20^{\circ} \mathrm{C}$.

Iodination. The hormones for iodination were FSH (NIAMDD-rat-FSH-I-4) and hCG (Calbiochem, LaJolla, California), 10605 i.u./mg. The hormones were iodinated by the chloramine-T method, a modification of the procedure of Butt (1972). Sephadex G-75 was used to separate the labelled hormone from free ${ }^{125} \mathrm{I}$. For competitive tests, the unlabelled hormones used were NIAMDD-rat-FSH-RP1 and hCG (Calbiochem, 2000 i.u./mg). The specific activities for the labelled hormones were approximately $33.25 \mu \mathrm{Ci} / \mu \mathrm{g}$ protein and $51.2 \mu \mathrm{Ci} / \mu \mathrm{g}$ protein for FSH and hCG, respectively. The specific activities for hormones used in the second group of experiments (Table 2) were $31.13 \mu \mathrm{Ci} / \mu \mathrm{g}$ protein for $\mathrm{FSH}$ and $18.34 \mu \mathrm{Ci} / \mu \mathrm{g}$ protein for $\mathrm{hCG}$.

Preparation of slides. The sections were incubated for $1 \mathrm{~h}$ in moist chambers with $25 \mu \mathrm{l}$ of labelled hormones diluted in $0.01 \mathrm{M}$-PBS with $1 \%$ egg white to give concentrations of FSH and hCG of approximately 6 and $4 \mathrm{ng} / \mathrm{ml}$, respectively. The counts for FSH applied to slides were $1.0 \times 10^{4}$ counts $/ 25 \mu \mathrm{l} / \mathrm{min}$ and for hCG $1.2 \times 10^{4}$ counts $/ 25 \mu \mathrm{l} / \mathrm{min}$. For the second set of experiments the counts applied for FSH and hCG were $1.2 \times 10^{4}$ counts $/ 25 \mu \mathrm{l} / \mathrm{min}$, the concentration of hormones being $4 \mathrm{ng} \mathrm{FSH} / \mathrm{ml}$ and $12 \mathrm{ng} \mathrm{hCG} / \mathrm{ml}$. These concentrations were chosen because previous studies in our laboratory have demonstrated that these values were optimal for quantitative studies under our experimental conditions. To check the specificity of binding (Midgley, 1973), competitive tests were performed on parallel sections by adding an excess of the unlabelled homologous (rat FSH for labelled rat FSH and unlabelled hCG for labelled hCG) or heterologous (rat FSH for labelled hCG and hCG for labelled rat FSH) hormone. After incubation the slides were washed, fixed in PBS-3\% glutaraldehyde and dipped in Kodak NTB 2 nuclear track emulsion (Eastman Kodak, Rochester, New York) and exposed at $0-4{ }^{\circ} \mathrm{C}$ for $40 \mathrm{~h}$. A separate group of slides was exposed for 9 days. After development, the sections were stained with nuclear fast red stain and saturated alcoholic picric acid and mounted in permount.

Quantification. Photomicrographs were taken at random from each slide of adjacent sections exposed for $40 \mathrm{~h}$ and silver grains were counted. Both ovaries from 3 animals were used for each group. From each animal 3 large antral follicles were selected for photography. For thecal and 


\section{PLATE 1}
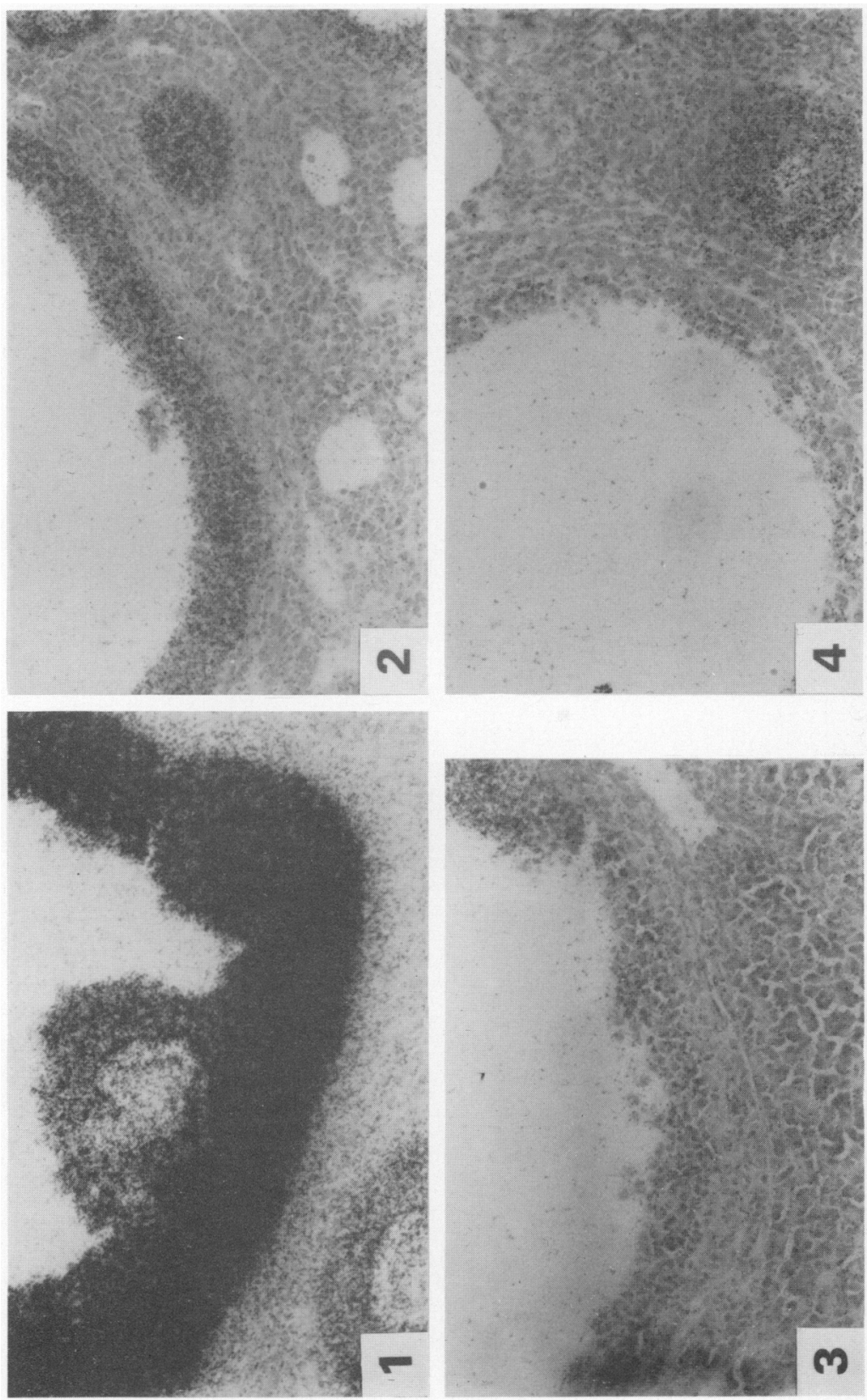

All slides were exposed for 9 days before developing.

Fig. 1. Autoradiograph showing binding of ${ }^{125} \mathrm{I}$-labelled FSH to granulosa cells of an antral follicle before injection of PMSG antiserum (time zero). $\times 185$.

Figs 2-4. Binding of ${ }^{125} \mathrm{I}$-labelled FSH to granulosa cells of ovarian follicles 24 (Fig. 2), 48 (Fig. 3) and 72 (Fig. 4) $\mathrm{h}$ after the injection of antiserum to PMSG. $\times 185$. 


\section{PLATE 2}
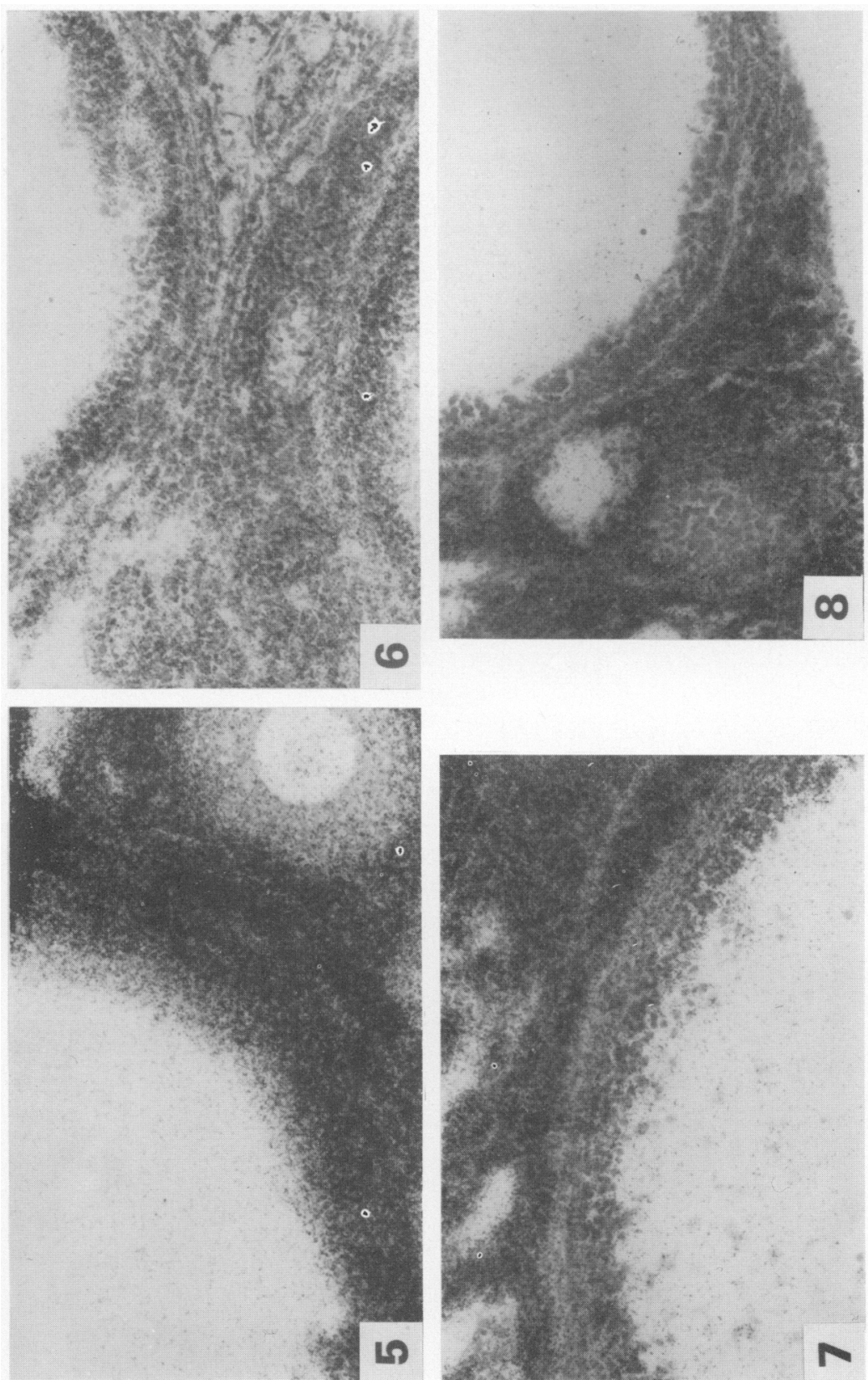

Fig. 5. Autoradiograph showing binding of ${ }^{125} \mathrm{I}$-latelled $\mathrm{hCG}$ to granulosa cells of an antral follicle and to the interstitium at time zero. $\times 185$.

Figs 6-8. Binding of ${ }^{125} \mathrm{I}$-labelled hCG to the granulosa cells and the interstitium at 24 (Fig. 6), 48 (Fig. 7) and 72 (Fig. 8) h after induction of atresia. $\times 185$. 
interstitial compartments two areas were selected per animal and photographed. For the second set of experiments 7-9 follicles per animal were counted. The granulosa cells and interstitium were photographed at $\times 250$ while the theca was filmed at $\times 900$ magnification. As shrinkage of granulosa cells occurs with atresia, the grains were counted and expressed per cell whereas for thecal and interstitial cells the grains were expressed as per $100 \mathrm{~mm}^{2}$. The areas on the photomicrographs were measured on a digitizer (software was supplied by Ralph L. Smith Computer Center). Values obtained in equivalent areas of sections where competitive tests were performed with excess homologous hormones were assumed to correspond to non-specific binding plus background values.

Statistics. To compare the values for Groups 0, 1, 2 and 3 and those for groups in the second set of experiments, a one-way analysis of variance followed by Duncan's new multiple range test was performed. To compare counts from sections incubated with excess unlabelled heterologous hormone and those incubated only with labelled hormone a paired $t$ test was performed. The level of significance was considered to be $P<0.05$ or lower.

\section{Results}

\section{Qualitative changes in binding of iodinated gonadotrophins to the ovary}

Tissue sections incubated with ${ }^{125}$ I-labelled FSH or ${ }^{125}$ I-labelled hCG revealed highly specific binding to different tissue compartments which was almost completely inhibited by excess of unlabelled homologous hormone but not significantly affected by unlabelled heterologous hormone, thus indicating the high specificity of the binding.

\section{General pattern of gonadotrophin uptake}

In slides exposed for 9 days, sections incubated with ${ }^{125}$ I-labelled FSH revealed localization of silver grains over the granulosa cells of the antral follicles. Theca and interstitium did not show any appreciable number of silver grains. As shown in Pl. 1, Fig. 1, the number of silver grains was very high in Group 0, dropped sharply in Group 1 and steadily in Groups 2 and 3 (Pl. 1, Figs 2-4). The number of silver grains in Group 2 was less than that in Group 1. ${ }^{125}$ I-labelled hCG bound to the granulosa cells of antral follicles, the thecal cells and interstitial cells. There was a drop in the number of silver grains in the granulosa cells comparable to that seen for binding of ${ }^{125} \mathrm{I}$-labelled FSH (see Pl. 2, Figs 5-8).

The distribution of silver grains over the interstitial and thecal cells did not differ significantly during the $72 \mathrm{~h}$ period (P1. 2, Figs 2 and 3 ).

\section{Quantitative aspects of binding after induced follicular atresia}

The decline in grains/granulosa cell was much more precipitous for FSH than for hCG. There were no significant differences in the binding of hCG to thecal or interstitial cells over the 72-h time span of induced atresia (Table 1). There was no significant difference in grain counts between animals killed at time 0 and animals treated with NRS and killed $24 \mathrm{~h}$ later, thus showing the ability of PMSG to maintain follicular growth beyond Day 4. Animals treated with PMSG antiserum on Day 4 and killed $24 \mathrm{~h}$ later showed significant differences in counts of silver grains (Table 2).

The difference in the number of silver grains per cell in the two sets of experiments involving hCG (Tables 1 and 2) is attributable to the difference in specific activity of the labelled hormone (see 'Materials and Methods'). 
Table 1. Binding of ${ }^{125} \mathrm{I}$-labelled FSH and ${ }^{125} \mathrm{I}$-labelled $\mathrm{hCG}$ to different ovarian cell types during induced follicular atresia in hamsters

\begin{tabular}{|c|c|c|c|c|}
\hline Cell type & $\begin{array}{l}\text { No. of } \\
\text { animals }\end{array}$ & Hormone & $\begin{array}{l}\text { Time killed } \\
\text { after PMSG } \\
\text { antiserum (h) }\end{array}$ & $\begin{array}{c}\text { Counts } \\
\text { (mean } \pm \text { s.e.m.) }\end{array}$ \\
\hline Granulosa cells & 3 & FSH & $\begin{array}{r}0 \\
24 \\
48 \\
72\end{array}$ & $\begin{array}{c}\text { Grains/cell } \\
13 \cdot 55 \pm 1 \cdot 69 \\
4.20 \pm 0.45^{*} \\
1.74 \pm 0.12^{*} \\
0.62 \pm 0.22^{*} \dagger\end{array}$ \\
\hline Granulosa cells & 3 & hCG & $\begin{array}{r}0 \\
24 \\
48 \\
72\end{array}$ & $\begin{array}{c}12.71 \pm 1.00 \\
5.95 \pm 1.25^{*} \\
3.48 \pm 0.15^{*} \\
2.99 \pm 1.00^{*} \dagger\end{array}$ \\
\hline Interstitial cells & 3 & hCG & $\begin{array}{r}0 \\
24 \\
48 \\
72\end{array}$ & $\begin{array}{c}\text { Grains/100 } \mathrm{mm}^{2} \\
12.49 \pm 2.05 \\
8.93 \pm 1.04 \\
13.18 \pm 1.36 \\
8.58 \pm 1.28\end{array}$ \\
\hline Thecal cells & 3 & $\mathrm{hCG}$ & $\begin{array}{r}0 \\
24 \\
48 \\
72\end{array}$ & $\begin{array}{l}1.96 \pm 1.00 \\
1.19 \pm 0.21 \\
2.38 \pm 0.37 \\
1.98 \pm 0.92\end{array}$ \\
\hline
\end{tabular}

* Significantly different from the $0 \mathrm{~h}$ value, $P<0.01$.

† Significantly different from the value at $24 \mathrm{~h}, P<0.05$.

Table 2. Binding of ${ }^{125} \mathrm{I}$-labelled FSH and ${ }^{125}$-labelled hCG to granulosa cells in hamsters treated with PMSG, normal rabbit serum (NRS) and antiserum to PMSG

\begin{tabular}{lcccc}
\hline Treatment & $\begin{array}{c}\text { No. of } \\
\text { animals }\end{array}$ & $\begin{array}{c}\text { Time after } \\
\text { treatment }(\mathrm{h})\end{array}$ & Hormone & $\begin{array}{c}\text { Grains/granulosa cell } \\
\text { (mean } \pm \text { s.e.m.) }\end{array}$ \\
\hline PMSG & 4 & 0 & FSH & $15.37 \pm 1.41$ \\
NRS & 4 & 24 & FSH & $13.24 \pm 1.69$ \\
PMSG antiserum & 3 & 24 & FSH & $4.27 \pm 1.52^{*}$ \\
PMSG & 4 & 0 & hCG & $5.02 \pm 0.32$ \\
NRS & 3 & 24 & hCG & $4.06 \pm 1.37$ \\
PMSG antiserum & 3 & 24 & hCG & $0.72 \pm 0.32^{*}$ \\
\hline
\end{tabular}

* Significantly different from the values for the other two groups, $P<0.05$.

\section{Discussion}

After the induction of follicular atresia by PMSG antiserum, the binding of labelled FSH and hCG to granulosa cells dropped sharply during the first $24 \mathrm{~h}$ and decreased further at 48 and 72 $h$. However, the binding of ${ }^{125}$ I-labelled hCG to thecal and interstitial cells remained relatively constant throughout the 72-h period studied. In advanced stages of atresia there is loss of LH and FSH binding in the ewe (Carson, Findlay, Burger \& Trounson, 1979) and loss of LH binding in immature rats (Peluso, Steger \& Hafez, 1977).

Similarly, in a model of atresia based on postponing ovulation in pro-oestrous rats by daily administration of pentobarbitone sodium, binding to granulosa cells of atretic follicles of FSH and hCG decreases during a 4-day period; there was also no appreciable change in the binding of 
hCG to thecal cells over this period (Uilenbroek et al., 1980). In the present study, because of the acute deprivation of gonadotrophin support of the follicle, the changes in gonadotrophin binding sites occur very quickly.

Hubbard \& Greenwald (1981) incubated antral follicles at various times after atresia was induced in hamsters by treatment with PMSG antiserum. Oestradiol and testosterone levels dropped significantly in antral follicles and medium within $2 \mathrm{~h}$ whereas progesterone levels remained elevated even at $72 \mathrm{~h}$. This was associated with significant cell death of granulosa cells within $24 \mathrm{~h}$ as evidenced by a significant decline in DNA per follicle and ovarian histology; on the other hand, the theca was histologically normal but showed no signs of hypertrophy. The present finding that labelled hCG binding to thecal cells was unaffected for as long as $72 \mathrm{~h}$ after the induction of atresia suggests that the theca is the source of the prolonged synthesis of progesterone noted by Hubbard \& Greenwald (1981).

Both FSH and LH stimulate synthesis of $3^{\prime} 5^{\prime}$-cyclic AMP in antral follicles in the hamster (Makris \& Ryan, 1978). The decrease in binding of ${ }^{125} \mathrm{I}$-labelled FSH and ${ }^{125} \mathrm{I}$-labelled hCG to the follicle as atresia progresses (Table 1) could lead to the decrease in production of follicular cyclic nucleotides observed in this model by Hubbard \& Greenwald (1981). The presence of hCG receptors in large quantities in the interstitium even at $72 \mathrm{~h}$ may account for the fact that hamster ovaries deprived of gonadotrophins by hypophysectomy produce in vitro significant quantities of progesterone which can be further stimulated by LH (Taya \& Greenwald, 1980).

C. S. was a Ford Foundation Fellow. The research was supported by a grant from NIH (HD-00596). We thank Dr C. Hubbard for his help with area measurements and the NIAMDD for the ovine FSH.

\section{References}

Bill, C.H., II \& Greenwald, G.S. (1981) Acute gonadotropin deprivation. I. A model for the study of atresia. Biol. Reprod. 24, 913-922.

Bortolussi, M., Marini, G. \& Reolon, L. (1979) A histochemical study of the binding of ${ }^{125} \mathrm{I}$ hCG to the rat ovary throughout the estrus cycle. Cell Tiss. Res. 197, 213-226.

Braw, R.H. \& Tsafriri, A. (1980a) Follicles explanted from phenobarbitone treated rats provide a model for atresia. J. Reprod. Fert. 59, 259-265.

Braw, R.H. \& Tsafriri, A. (1980b) Effect of PMSG on follicular atresia in the immature rat ovary. J. Reprod. Fert. 59, 267-272.

Butt, W.R. (1972) The iodination of follicle stimulating hormone and other hormones for radioimmunoassay. $J$. Endocr. 55, 453-454.

Byskov, A.G. (1979) Atresia. In Ovarian Follicular Development and Function, pp. 41-57. Eds A. R. Midgley \& W. A. Sadler. Raven Press, New York.

Carson, R.S., Findlay, J.K., Burger, H.C. \& Trounson, A.O. (1979) Gonadotropin receptors of the ovine ovarian follicle during follicular growth and atresia. Biol. Reprod. 21, 75-87.

Greenwald, G.S. (1963) Effect of anti-PMS serum on superovulation in the hamster. Endocrinology 73, 436-441.

Greenwald, G.S. (1973) Effect of anti-PMS serum on ovulation and estrogen secretion in the PMS treated hamster. Biol. Reprod. 9, 437-446.

Hubbard, C.J. \& Greenwald, G.S. (1981) Changes in DNA, cyclic nucleotides and steroids during induced follicular atresia in the hamster. J. Reprod. Fert. 63, $455-461$.
Makris, A. \& Ryan, K.J. (1978) Cyclic AMP and cyclic GMP accumulation by hamster granulosa cells stimulated by LH and FSH. Acta endocr., Copenh. 89, 92-99.

Midgley, A.R. (1973) Gonadotropin binding to frozen sections of ovarian tissue. In Gonadotropins, pp. 248-260. Eds B. B. Saxena, C. G. Beling \& H. M. Gandy. Wiley Interscience, New York.

Peluso, J.J., Steger, R.W. \& Hafez, E.S.E. (1977) Sequential changes associated with degeneration of pre-ovulatory rat follicles. J. Reprod. Fert. 49, 215218.

Richards, J.S. \& Midgley, A.R. (1976) Protein hormone action: a key to understanding ovarian follicle and luteal cell development. Biol. Reprod. 14, 82-94.

Talbert, G.B., Meyer, R.K. \& McShan, W.H. (1951) Effect of hypophysectomy at the beginning of proestrus on maturing follicles in the ovary of the rat. Endocrinology 49, 687-694.

Taya, K. \& Greenwald, G.S. (1980) In-vitro and in-vivo ovarian steroidogenesis in the long term hypophysectomized hamster. Endocrinology 106, 10931098.

Terranova, P.F. (1980) Effect of phenobarbital induced ovulatory delay on the follicular population and serum levels of steroids and gonadotropins in the hamster: a model for atresia. Biol. Reprod. 23, 92-99.

Uilenbroek, J.Th.J., Woutersen, P.J.A. \& van der Schoot, P. (1980) Atresia of preovulatory follicles: gonadotropin binding and steroidogenic activity. Biol. Reprod. 23, 219-229.

Received 18 November 1981 